\title{
ECONOMIC ASSESSMENT OF LARGE POWER PHOTOVOLTAIC IRRIGATION SYSTEMS IN THE ECOWAS REGION
}

\author{
C. Lorenzo a , R. H. Almeida ${ }^{\text {a, b }}$, M. Martínez-Núñez a , L. Narvarte ${ }^{\text {a }, ~ L . ~ M . ~ C a r r a s c o ~ a ~}$ \\ ${ }^{a}$ Universidad Politécnica de Madrid, 28031 Madrid, Spain \\ ${ }^{\mathrm{b}}$ Instituto Dom Luiz, Faculdade de Ciências, Universidade de Lisboa, 1749-016 Lisboa, \\ Portugal \\ Corresponding author: celena.lorenzo@ies.upm.es, tlf. +34913365531, Instituto de Energía \\ Solar - Universidad Politécnica de Madrid, 28031 Madrid, Spain
}

\section{$\underline{\text { Abstract }}$}

This paper presents an economic assessment of large power (from tens to hundreds kWp) PV irrigation systems in the ECOWAS region, evaluating the economic feasibility of substituting diesel-powered and grid-powered systems with PV ones. Seven countries from the ECOWAS region were considered and two irrigation operating modes were compared (pumping to a water tank or at constant pressure). Net Present Cost (NPC) values are in the $0.33-41.5 \times 10^{5} \$$ range, Internal Rate of Return (IRR) values are in the $8-47 \%$ range and Payback Period (PBP) values are in the 2.1-10 years range. The economic savings in terms of Levelized Cost of Energy, LCOE, were also evaluated. LCOE for PV irrigation systems are in the 4.5-17.4 \$cents $/ \mathrm{kWh}$ range, which represent percentage savings of $30-84 \%$ if compared to diesel-powered and gridpowered systems.

Keywords: photovoltaic, irrigation system, economic assessment, renewable energy.

\section{Introduction}

Irrigation for agricultural applications is a very high water and electricity-consuming activity, as most of the water demanded must be pumped from underground reservoirs. Traditionally, water pumps are powered by the local electric grid, if accessible, or by diesel generators in isolated regions or in regions where the grid service is unreliable. In any case, diesel or electricity consumption represents a significant share of the economic cost required in any agricultural plantation. Solar photovoltaic (PV) generators to feed irrigation systems represent an attractive alternative for reducing the cost of this electricity consumption: they can be site-scaled, they permit stand-alone operation and they have a low environmental footprint. Also, they are economically competitive since the prices of PV panels started dropping in 2010 and were reduced to less than half in only 5 years [1].

Up-to-date reviews of the state of the art ([2], [3]), as well as recent international reports ([4], [5]) show that many studies have already evaluated the technical and economic viability of PV water pumping, for both drinking and irrigation applications. However, they all refer to systems with relatively small PV nominal power (up to $30 \mathrm{~kW}$ ), that present lower efficiencies and higher unit-cost than larger power systems. The aim of this work is to explore the feasibility of PV irrigation systems with enough power to supply water to professional agricultural 
exploitations (big farmers, irrigator communities and agro-industries) in the range of tens or hundreds of $\mathrm{kW}$.

Recently, the European MASLOWATEN project [6] has reported solutions that solve the technical problems associated to large power PV irrigation systems (like the effect of PV power intermittences, the integration in the previous existing irrigation network or the match between PV production and irrigation needs), evaluating them in 5 real-scale PV irrigation demonstrators installed in Spain, Portugal, Italy and Morocco, ranging from 40 to $360 \mathrm{kWp}$. The economic effectiveness of these large power systems has been evaluated, obtaining very encouraging results: the Payback Periods (PBP) for substituting the grid-connection or diesel generators in the range of 7-10 years, with Internal Rates of Return (IRR) in the range of 10-16\%. However, diesel prices, electricity tariffs, access to the grid and grid resiliency differ from the South of Europe to other regions of the planet, so these results are highly site-dependent. Therefore, it would be interesting to evaluate the economic feasibility of large power irrigation systems in other regions. One of particular interest is the ECOWAS (Economic Community of West African States) region [7], where institutions like the ECREEE (ECOWAS Centre for Renewable Energy and Energy Efficiency) or the World Bank are promoting renewable alternatives for agricultural applications [8]. ECOWAS countries are generally characterized by highly decentralized farms, with very limited or unreliable grid-access points. This has favored an abundance of diesel generators for back-up services, with the consequent elevated fuel and transportation costs.

The objective of this paper is to analyze the conditions in which the promising large power PV irrigation systems in stand-alone operation are economically feasible in the ECOWAS region. The analysis starts out with the experimental data from the MASLOWATEN demonstrators, for example, the actual CAPEX depending on their size (from 1.4 to $1.7 € / \mathrm{Wp}$ ), and focuses on the substitution of existing diesel or grid-powered systems with PV ones. Following the recommendation of other authors [9], the performance factors used in this economic evaluation are the PBP, the IRR, the Net Present Cost (NPC) and the Levelized Cost of Energy (LCOE), which have been calculated for 7 countries from the ECOWAS region. Four different cases were compared for these 7 countries: irrigation pumps could be originally powered with diesel generators or by the national grid (and both would be substituted by a PV generator), and they have two possible operating modes (pumping to a tank or at constant pressure).

This analysis can be useful for other regions and opens the door to rationalize future PV irrigation programs that could be boosted in these areas.

\section{Methodology}

The purpose of this paper is to evaluate the economic viability of large power PV irrigation systems in the ECOWAS region. Firstly, 7 PV irrigation systems were simulated in stand-alone operation for 7 countries, assuming they would be located in areas with high solar radiation and irrigation needs. It should be noted that these areas are intended to be generic examples of suitable locations, so factors like limited access to water have not been considered for reasons of simplicity. In the same way, only PV irrigation systems without batteries and without any other power sources are considered, therefore they are suitable for farms able to irrigate during the day. The objective of these simulations is to determine the water volume pumped by a given 
104

105

irrigation system, powered by a $380 \mathrm{kWp}$ PV generator, and how much PV energy (PVE) this system would produce over a whole year. Secondly, the viability of the economic investment required for substituting diesel generators or grid-connection points with a PV generator was evaluated through three indicators (NPC, IRR and PBP). Thirdly, the LCOE of the PV-powered systems was estimated and compared with the LCOE of diesel-powered systems and with the national electricity tariffs. Therefore, 4 case studies were considered, depending on whether the irrigation pumps were previously powered with diesel generators or by the national grid, and whether they operate by pumping to a water tank or at constant pressure. In addition, a sensitivity analysis was carried out to assess the effect on the profitability of local electricity tariffs, diesel prices and the size of the PV irrigation system.

\subsection{PV irrigation systems simulations}

The performance of PV irrigation systems has been simulated using a simulation tool called SISIFO [10]. There are further simulators and toolboxes available for PV irrigation systems [11], [12], but SISIFO links its results to just those inputs guaranteed by the different component manufacturers. This way, responsibilities can be assigned in case of underperformance, favouring the bankability of possible projects. Simulations were carried out for the 7 locations presented in Table 1. Based on it, SISIFO is able to import the monthly mean values of horizontal daily irradiation, as well as the maximum and minimum ambient temperatures for each place from the PVGIS database [13].

\begin{tabular}{cccc}
\hline Country & Region & Latitude $\left[{ }^{\circ}\right]$ & Longitude $\left[{ }^{\circ}\right]$ \\
\hline Benin & Parc National du W & 12.050 & 3.032 \\
Burkina Faso & Sahel Reserve & 14.881 & -0.1 \\
Cape Verde & Praia & 14.924 & -23.533 \\
Guinea & Dinguiraye & 11.222 & -10.723 \\
Liberia & Voinjama & 8.413 & -9.748 \\
Nigeria & Kano & 12.018 & -8.613 \\
Sierra Leone & Fintonia & 9.649 & -12.225 \\
\hline
\end{tabular}

TABLE 1. Location input used for the simulation of the PV irrigation systems.

Then, the mean-sky model is used to split the monthly mean daily horizontal global irradiation in its beam and diffuse components, which are calculated using the global diffuse correlations of Erbs [14]. The estimation of the instantaneous values of these components is made as described by Collares-Pereira and Rabl [15]. The Perez model [16] is used for transposition from horizontal to in-plane diffuse irradiances. The Martinez shading model [17] is also used in this simulation. As regards ambient temperatures, the simulation tool is able to generate the time series using a cosine type interpolation model.

The next step is related to the inputs of the electrical characteristics of the PV modules (Table 2) and PV generator structure (Table 3). The $380 \mathrm{kWp} \mathrm{PV} \mathrm{generator} \mathrm{is} \mathrm{mounted} \mathrm{on} \mathrm{a} \mathrm{North-South}$ horizontal axis tracker due to its better match between incident irradiance and irrigation needs. It should be highlighted that tracking systems are not usually considered for smaller irrigation 
systems, as they increase the initial investment and maintenance costs. However, in large power systems the energy gain and the constant daily power profile (which matches the dynamics of the well) obtained using a tracker are important enough to justify a bigger economic effort. Wiring losses in the DC part of the system are 1.5\% and in the AC part are 3\% (Table 4).

\begin{tabular}{l|c}
\hline Parameter & Value \\
\hline Cell material & Crystalline silicon \\
Nominal power of each PV module $[\mathbf{W p}]$ & 250 \\
Power model & Only temperature effect \\
Coefficient of variation of power with temperature $-\gamma\left[\mathbf{\%}^{\circ}{ }^{\circ} \mathbf{C}\right]$ & -0.420 \\
Nominal operating cell temperature - NOCT $\left[{ }^{\circ} \mathbf{C}\right]$ & 45 \\
\hline
\end{tabular}

TABLE 2. Parameters of the PV module.

\begin{tabular}{l|c}
\hline Parameter & Value \\
\hline Separation between trackers in E-W direction & 3 \\
Maximum rotation angle $\left[^{\circ}\right]$ & 45 \\
Axis orientation $\left[{ }^{\circ}\right]$ & 0 \\
Axis inclination $\left[{ }^{\circ}\right]$ & 0 \\
Separation between tracker rows in N-S direction & 1 \\
Module inclination $\left[{ }^{\circ}\right.$ ] & 0 \\
Backtracking option & Yes \\
\hline
\end{tabular}

TABLE 3. Parameters of the North-South horizontal axis tracker.

\begin{tabular}{c|c}
\hline Parameter & Value \\
\hline DC losses [\%] & 1.5 \\
\hline AC losses [\%] & 3 \\
\hline
\end{tabular}

TABLE 4. Wiring parameters.

According to the characteristics of the previously defined irrigation systems (one pumping to a water tank and the other at a constant working pressure), the Caprari E10S50/11B MAC10220$8 \mathrm{~V}$ is used, as well as a $220 \mathrm{~kW}$ OMRON frequency converter. Table 5 summarizes the main characteristic of the systems.

\begin{tabular}{l|c|c|}
\cline { 2 - 3 } & Water pool & Constant pressure \\
\hline Parameter & Value & Value \\
\hline PV generator size $[\mathbf{k W p}]$ & 380 & 380 \\
Nominal power of the frequency converter $[\mathbf{k W}]$ & 220 & 220 \\
Type of PV irrigation system & Stand-alone & Stand-alone \\
Type of pumping & Water pool & Constant pressure \\
Static head $[\mathbf{m}]$ & 200 & 170 \\
Friction losses at rated flow [m] & 20 & 20 \\
Working pressure [m] & Variable & 30 \\
Working flow $\left[\mathbf{m}^{\mathbf{3}} / \mathbf{h}\right]$ & Variable & 200 \\
\hline
\end{tabular}

TABLE 5. PV generator size, inverter and pumping characteristics. 
137 Figure 1 includes the characteristic curves of the pump (at $50 \mathrm{~Hz}$ ) and the hydraulic system and 138 Table 6 summarizes the characteristics of the motor.

139

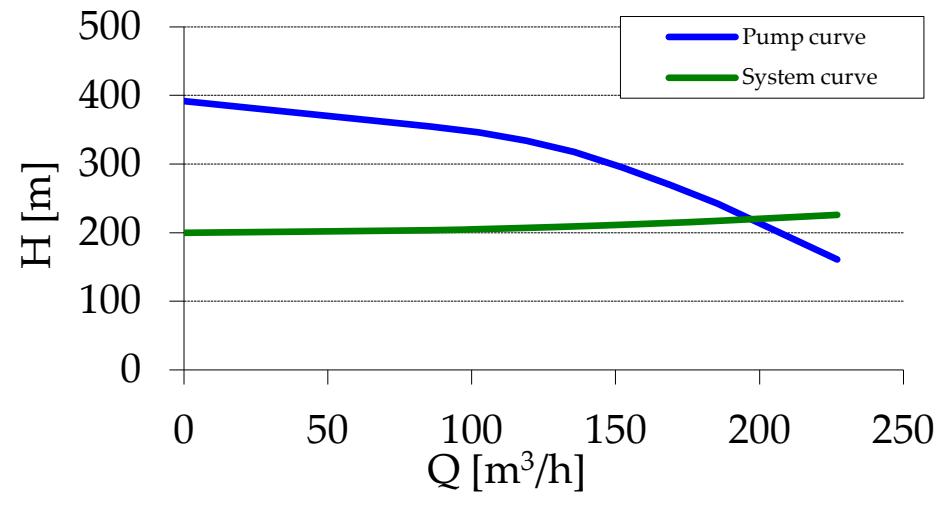

FIGURE 1. Pump and system curves.

\begin{tabular}{c|c} 
Parameter & Value \\
\hline Nominal power [kW] & 165 \\
Nominal RPM & 2933.8 \\
Minimum RPM [\% of nominal] & 60 \\
Maximum RPM [\% of nominal] & 110 \\
Nominal frequency [Hz] & 50
\end{tabular}

TABLE 6. Characteristics of the motor.

Advanced options influencing the simulation of the system are included in Table 7. Finally, it should be mentioned that all days of the year are simulated, with hourly resolution and using solar time.

\begin{tabular}{l|c} 
Parameter & Value \\
\hline Soiling [\%] & 2 \\
Spectral response & Yes \\
Diffuse model & Perez \\
Monthly diffuse correlation & Erbs \\
Shading model & Martinez \\
Minimum irradiance [W/m $\left.{ }^{2}\right]$ & 10 \\
Ground reflectance [] & 0.2
\end{tabular}

TABLE 7. Advanced simulation options.

\subsection{Economic viability analysis}

For estimating the values of NPC, IRR and PBP for a monetary investment, the annual Cash Flows (CF) need to be calculated for the whole lifetime of the system (25 years), considering both the annual Profits (P) obtained and the Amortization (AM) of the Initial Investment Cost (IIC). In the particular case assessed in this paper, the annual profits are given by the economic 
savings derived from substituting the national grid (no electricity tariffs would have to be paid) or diesel generators (no diesel fuel would need to be bought) with a PV generator. Entries from selling the crops obtained with the water pumped are not significant in this analysis, as they are the same independently of how the system is powered. In other words, the viability of the PV system is evaluated in terms of the variation in the CF before and after the installation of the PV generator. $\mathrm{CF}$ for the year $n$, for a grid-powered $\left(C F_{g, n}\right)$ and for a diesel-powered $\left(C F_{d, n}\right)$ system are given by equations (1) and (2):

$$
\begin{gathered}
C F_{g, n}=\left(E-E C_{n}\right) \times(1-t) \\
C F_{d, n}=\left(E-D C_{n}\right) \times(1-t)
\end{gathered}
$$

where $E$ is the entry obtained from selling the crops, $E C_{n}$ is the cost of the electricity consumed by the grid-powered irrigation system, $D C_{n}$ is the cost of the diesel consumed by the dieselpowered system and $t$ is the corporate tax rate for a given country.

EC and DC for the year $n$ are given by equations (3) and (4):

$$
\begin{aligned}
& E C_{n}=E P \times P V E_{n} \\
& D C_{n}=D P \times P V E_{n} \times d f c
\end{aligned}
$$

where $E P$ is the electricity price given by the national electricity tariffs, $D P$ is the diesel price per volume unit, $\mathrm{PVE}_{\mathrm{n}}$ is the annual energy generation (assuming that $\mathrm{PV}$ modules experience no degradation in the first 5 years of their lifetime and a constant annual degradation of $0.8 \%$ after that [18]) and $d f c$ is the average diesel fuel consumption per energy unit, which has been given a value of $0.2861 / \mathrm{kWh}$ according to experimental data [6].

$\mathrm{CF}$ for the year $n$, for a PV-powered system $\left(C F_{p v}\right)$ is given by equation (5):

$$
C F_{p v, n}= \begin{cases}-I I C & (\text { if } n=0) \\ (E-O M-R C-A M) \times(1-t)+A M & (\text { if } n \neq 0)\end{cases}
$$

where $O M$ is the annual Operation and Maintenance Cost and $R C$ is the annual Replacement Cost of the PV system, including the irrigation pumps. These two annual costs, together with the ICC, determine the Life Cycle Cost (LCC) of a PV system [19].

The variation in $\mathrm{CF}$ for the year $n$ when substituting a grid-powered $\left(\Delta C F_{g, n}\right)$ or a dieselpowered system $\left(\Delta C F_{d, n}\right)$ with a PV powered one is given by equations (6) and (7):

$$
\begin{aligned}
& \Delta C F_{g, n}= \begin{cases}-I I C & \text { if } n=0) \\
C F_{p v, n}-C F_{g, n}=\left(E C_{n}-O M-R C\right) \times(1-t)+A M \times t & \text { if } n \neq 0)\end{cases} \\
& \Delta C F_{d, n}= \begin{cases}-I I C & \text { if } n=0) \\
C F_{p v, n}-C F_{d, n}=\left(D C_{n}-O M-R C\right) \times(1-t)+A M \times t & (\text { if } n \neq 0)\end{cases}
\end{aligned}
$$


192

$\mathrm{OM}$ and RC were estimated as $2 \%$ of the IIC each [20] and AM was calculated assuming a constant amortization linear coefficient of $7 \%$ of the IIC [21]. The IIC of the PV irrigation system was estimated at a unit cost of $1.7 \$ / \mathrm{Wp}$ [6] -consistent with the values obtained in previous studies [22]-, assuming a 20\% cost overrun in the ECOWAS region compared to the South of Europe (where the CAPEX is $1.4 \$ / \mathrm{Wp}$ ), due to the decentralized character of farms in the region.

Once $\Delta C F_{g, n}$ and $\Delta C F_{d, n}$ are calculated for the lifetime of the system (25 years), the NPC can be estimated according to equations (8) and (9):

$$
\begin{aligned}
& N P C_{g}=\Delta C F_{g, 0}+\sum_{n=1}^{25} \frac{\Delta C F_{g, n}}{(1+i)^{n}} \\
& N P C_{d}=\Delta C F_{d, 0}+\sum_{n=1}^{25} \frac{\Delta C F_{d, n}}{(1+i)^{n}}
\end{aligned}
$$

where $i$ is the real interest rate for a certain country, given by equation (10) [23], [24]:

$$
i=\frac{\left(i^{\prime}-f\right)}{(1+f)}
$$

where $i^{\prime}$ is the nominal interest rate and $f$ is the annual GDP deflator rate (which applies to all the economic activities in a country, including final goods and services). When equation (10) gives a negative value for $i$ (which means that it is necessary to pay an interest rate for investing in a national bank, instead of making a profit), the NPC calculations are made with $i=0$ [24].

Finally, the IRR is defined as the real interest rate that would make NPC $=0$ after 25 years (i.e. the real interest rate at which the initial investment is returned at the end of the lifetime of the project [9]), and PBP is defined as the number of years ( $n$ ) for which $\sum_{n=0}^{25} \Delta C F_{g, n}=0$ (i.e. the period of time required for the initial investment to be returned with the present value of cash flows, disregarding the real interest rate [9]).

Some input variables used in this economic model are country-dependent. Table 8 shows the

\begin{tabular}{|c|c|c|c|c|c|c|}
\hline Country & $\begin{array}{c}\text { EP }(\$ / k W h) \\
{[25]}\end{array}$ & $\begin{array}{c}\mathrm{DP}(\$ / \mathbf{l}) \\
{[26]} \\
\end{array}$ & $\begin{array}{c}\mathbf{t}(\%) \\
{[27]}\end{array}$ & $\begin{array}{c}\text { i' (\%) } \\
{[28]}\end{array}$ & $\begin{array}{c}f(\%) \\
{[29]}\end{array}$ & $\begin{array}{c}\text { i (\%) } \\
{[23],[24]}\end{array}$ \\
\hline Benin & 0.23 & 0.82 & 9.96 & 5.6 & -0.2 & 5.8 \\
\hline Burkina Faso & 0.25 & 0.94 & 16.24 & 5.6 & 2.9 & 2.6 \\
\hline Cape Verde & 0.33 & 0.97 & 18.26 & 9.6 & -0.9 & 10.6 \\
\hline Guinea & 0.16 & 0.89 & 0 & 4.8 & 10.6 & 0 \\
\hline Liberia & 0.56 & 0.83 & 35.35 & 13.6 & 5 & 8.2 \\
\hline Nigeria & 0.20 & 0.55 & 17.46 & 16.9 & 9.6 & 6.7 \\
\hline Sierra Leone & 0.26 & 0.78 & 17.27 & 18 & 4.2 & 13.24 \\
\hline
\end{tabular}
values assigned to these input variables for the 7 selected countries, together with the corresponding references from which they were obtained. 
208

209

210

211

212

213

214

215

216

217

218

219

220

221

222

223

224

225

226

227

228

229

230

231

232

233

234

LCOE is defined as the lifetime cost of a certain energy generation system divided by the total energy production during this lifetime. It is given by equation (11) [30], [31]:

$$
L C O E=\frac{\sum_{n=0}^{25} \frac{\left(I I C+O M+F C_{n}\right)}{(1+i)^{n}}}{\sum_{n=0}^{25} \frac{P V E_{n}}{(1+i)^{n}}}
$$

where $F C_{n}$ is the Fuel Cost necessary to operate the system for the year $n$. For PV-powered irrigation systems, $F C_{n}$ is zero and $O M$ is estimated as $2 \%$ of the $I I C$ [20]; for diesel powered systems, $I I C$ is zero, $O M$ is assumed to be $40 \$ / \mathrm{kW}$ per year [32] and $F C_{n}$ is equal to $D C_{n}$; for grid-powered systems, LCOE is equivalent to the electricity tariff.

\section{Results}

\subsection{PV irrigation systems simulations}

Table 9 summarizes the yearly mean of the daily water volume pumped and the energy consumed - in terms of DC electricity and volume of diesel- by the simulated systems, for the 7 given countries. It is observed that the water volume pumped is always higher when the system is pumping to a water tank than at constant pressure. This difference appears because in the first case the operation point is not constant, since the frequency of the pump varies with the instantaneous available PV power. On the other hand, pumping at constant pressure means working in a specific point of the pump curve, with both constant pressure and flow and, as a consequence, constant power. In other words, when pumping to a water tank it is possible to operate at the PV Maximum Power Point (MPP); when pumping at constant pressure, the PV generator generally operates at a lower power point.

\begin{tabular}{|c|c|c|c|c|c|c|}
\hline \multirow[b]{2}{*}{ Country } & \multicolumn{3}{|c|}{ To a water tank } & \multicolumn{3}{|c|}{ At constant pressure } \\
\hline & $\begin{array}{c}\text { Water } \\
\text { (m³/day) }\end{array}$ & $\begin{array}{c}\mathbf{E}_{\mathrm{DC}} \\
(\mathbf{M W h})\end{array}$ & $\begin{array}{l}\text { Diesel } \\
\left(\mathbf{x 1 0}^{3} \mathrm{I}\right)\end{array}$ & $\begin{array}{c}\text { Water } \\
\left(\mathbf{m}^{3} / \text { day }\right)\end{array}$ & $\begin{array}{c}\mathbf{E}_{\mathrm{DC}} \\
(\mathrm{MWh})\end{array}$ & $\begin{array}{l}\text { Diesel } \\
\left(\mathbf{x 1 0}^{3} \mathrm{l}\right)\end{array}$ \\
\hline Benin & 2343 & 913.9 & 261.1 & 1769 & 606.6 & 173.3 \\
\hline Burkina Faso & 2361 & 949.1 & 271.2 & 1832 & 628.6 & 179.6 \\
\hline Cape Verde & 2321 & 932.5 & 266.4 & 1800 & 617.1 & 176.3 \\
\hline Guinea & 2346 & 918.4 & 262.4 & 1800 & 617.5 & 176.4 \\
\hline Liberia & 2283 & 851.8 & 243.4 & 1667 & 571.6 & 163.3 \\
\hline Nigeria & 2344 & 916.8 & 261.9 & 1783 & 611.7 & 174.7 \\
\hline Sierra Leone & 2299 & 866.9 & 247.7 & 1769 & 606.6 & 173.3 \\
\hline
\end{tabular}

TABLE 9. Yearly mean of the daily water volume pumped ( $\mathrm{m}^{3} /$ day), DC energy consumed $(\mathrm{MWh})$ and the equivalent volume of diesel consumed $\left(\times 10^{3} 1\right)$ by the simulated irrigation systems over a whole year of operation, for the 7 countries under study. 
236 Figures 2, 3 and 4 show the values of NPC, IRR (together with the real discount rate in each country for their comparison) and PBP obtained for the 7 countries and for the 4 cases under study. Substituting an existing grid-powered or diesel-powered irrigation system with a PVpowered system would be cost effective when NPC is positive, IRR is higher than the local discount rate [33] and PBP is significantly lower than the lifetime of the system (25 years). It can be observed that these conditions are met for all the cases under study.

242 If comparing the 7 countries in terms of NPC, Guinea offers the best profitability for the substitution of diesel-powered systems because of its elevated diesel price and its low real discount rate and corporate tax rate (both equal to zero); Burkina Faso presents the highest profitability for the substitution of grid-powered systems due to its low real interest rate, although it has an intermediate electricity price. In terms of IRR, Guinea also offers the best profitability for the substitution of diesel-powered systems because fuel is very expensive in this country, which implies big savings for a PV powered system, and the income tax rate is zero; Liberia offers the highest IRR for the substitution of a grid-powered system due to the elevated electricity prices, despite it having the highest income tax rate.

251 If comparing the 4 cases under study, the substitution of diesel-powered systems pumping to a water tank are the most cost effective in Benin, Burkina Faso and Guinea, while the substitution of grid-powered systems pumping to a water tank are the most cost effective in Cape Verde, Liberia, Nigeria and Sierra Leone. In general terms, PV irrigation systems working at constant pressure have lower profitabilities because they are able to pump a smaller volume of water with the same PV generator capacity, which implies a lower economic entry for the same IIC.

As regards PBP values, they are less than 10 years for all the cases under study, and lower than

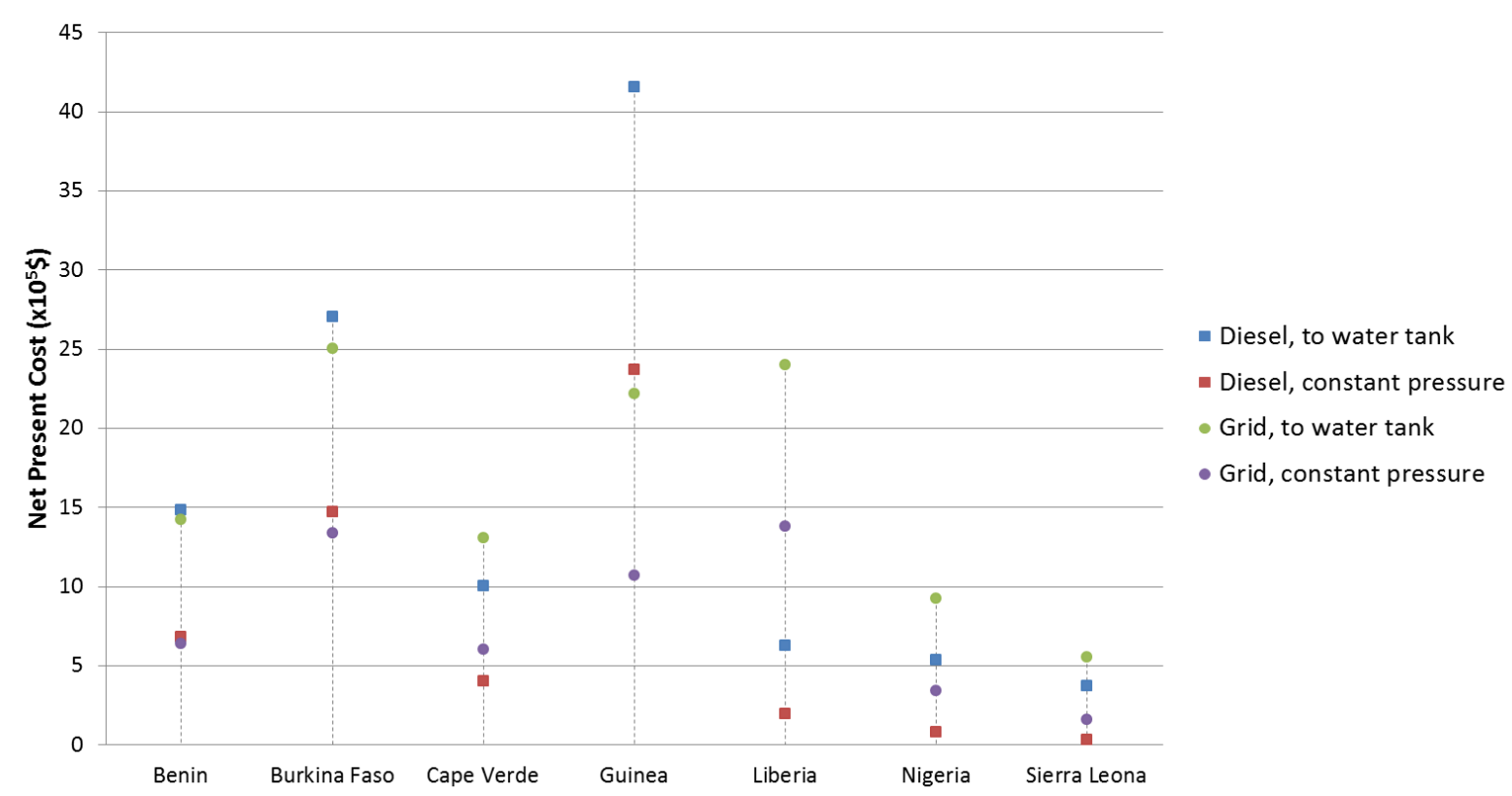

FIGURE 2. NPC $\left(x 10^{5} \$\right)$ for the 7 countries and the 4 cases under study: substitution of diesel generators or the grid with PV irrigation systems, for both operating modes (to a water tank or at constant pressure). 


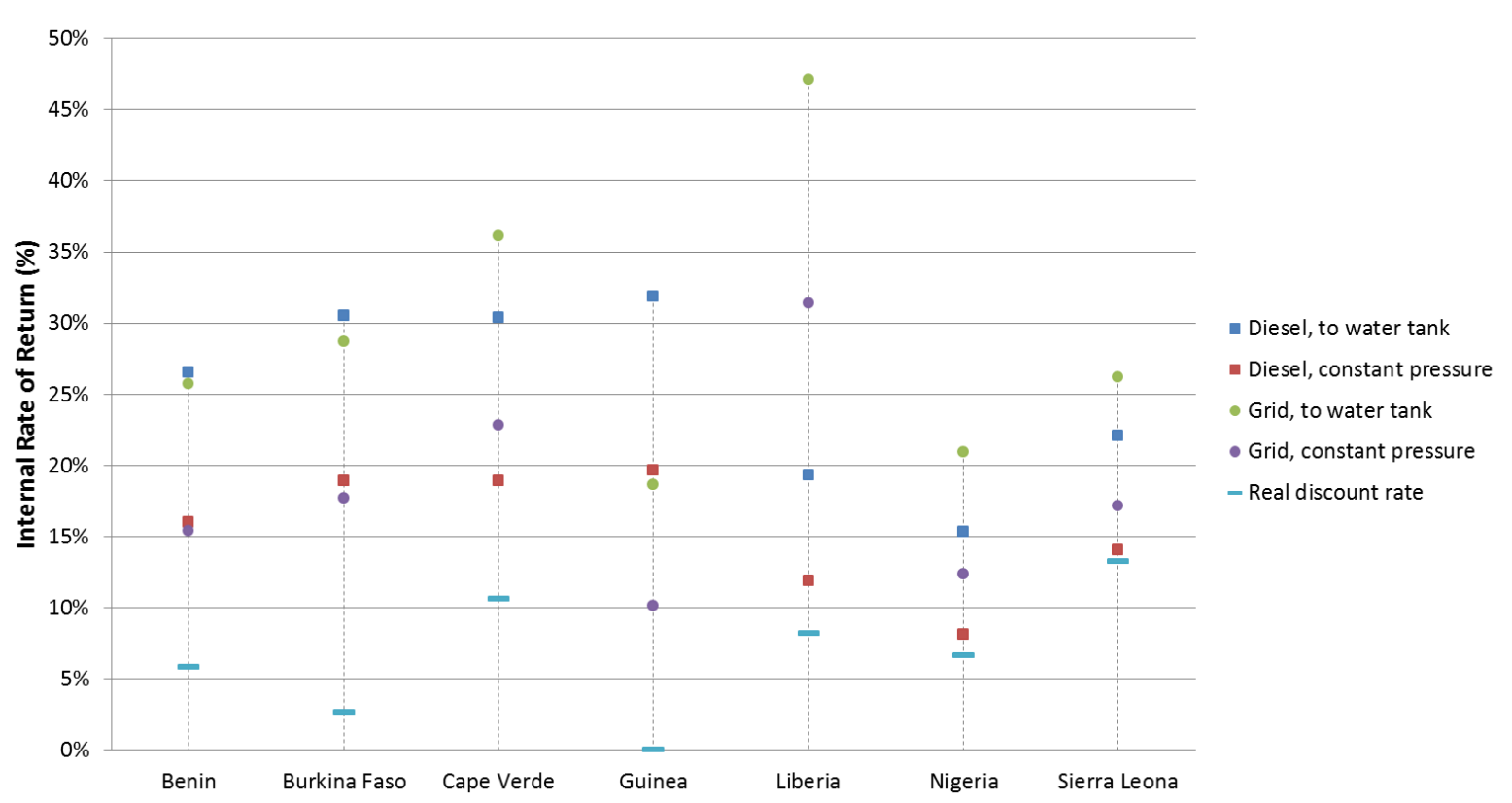

FIGURE 3. IRR (\%) and local i (\%) for the 7 countries and the 4 cases under study: substitution of diesel generators or the grid with PV irrigation systems, for both operating modes (to a water tank or at constant pressure)

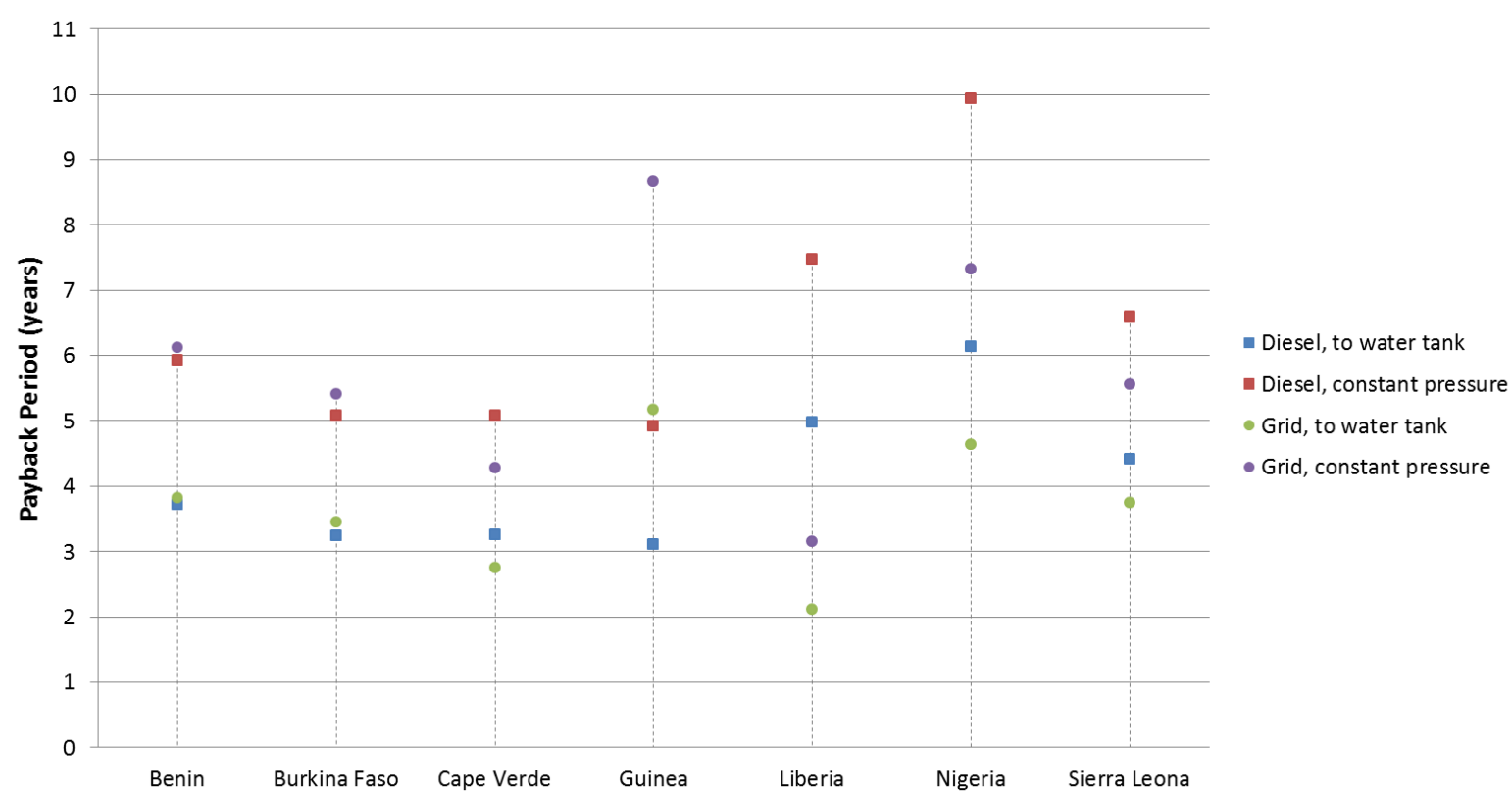

FIGURE 4. PBP (years) for the 7 countries and the 4 cases under study: substitution of diesel generators or the grid with PV irrigation systems, for both operating modes (to a water tank or at constant pressure)

275 Table 10 and Figure 5 show the values of LCOE obtained for diesel-powered and PV-powered systems pumping to a water tank (a) and at constant pressure (b), together with electricity prices 
277 for the 7 countries under study. Values between brackets in Table 10 represent the percentage 278 saving in terms of LCOE for PV irrigation systems compared to grid-powered and diesel279 powered systems, respectively. Generally, LCOE are smaller for systems pumping to a water 280 tank than at constant pressure, as they are able to pump more water with the same power 281 capacity. It is important to highlight that generating electricity for irrigation applications would 282 be cheaper by far with a PV generator than with the electric grid or with diesel generators: percentage savings are all higher than $30 \%$, the majority of them higher than $50 \%$.

\begin{tabular}{|c|c|c|c|c|c|}
\hline \multirow[b]{2}{*}{ Country } & \multirow[b]{2}{*}{$\begin{array}{c}\begin{array}{c}\text { Electricity price } \\
(\$ c e n t s / \mathbf{k W h})\end{array} \\
\end{array}$} & \multicolumn{4}{|c|}{ LCOE (\$cents/kWh) } \\
\hline & & $\begin{array}{c}\text { Diesel, to water } \\
\text { tank }\end{array}$ & $\begin{array}{c}\text { Diesel, constant } \\
\text { pressure }\end{array}$ & $\begin{array}{c}\text { PV, to water } \\
\text { tank }\end{array}$ & $\begin{array}{c}\text { PV, constant } \\
\text { pressure }\end{array}$ \\
\hline Benin & 22.8 & 25.2 & 26.1 & $\begin{array}{c}7.2 \\
(69)(71)\end{array}$ & $\begin{array}{c}10.8 \\
(53)(59)\end{array}$ \\
\hline Burkina Faso & 25.4 & 28.6 & 29.4 & $\begin{array}{c}5.4 \\
(79)(81)\end{array}$ & $\begin{array}{c}8.2 \\
(68)(72)\end{array}$ \\
\hline Cape Verde & 32.5 & 29.6 & 30.3 & $\begin{array}{c}9.7 \\
(70)(67)\end{array}$ & $\begin{array}{l}14.6 \\
(55)(52)\end{array}$ \\
\hline Guinea & 16.4 & 27.2 & 28.1 & $\begin{array}{c}4.5 \\
(72)(83)\end{array}$ & $\begin{array}{c}6.7 \\
(59)(76)\end{array}$ \\
\hline Liberia & 55.6 & 25.6 & 26.5 & $\begin{array}{c}9.1 \\
(84)(64)\end{array}$ & $\begin{array}{c}13.6 \\
(76)(49)\end{array}$ \\
\hline Nigeria & 20.2 & 17.5 & 18.3 & $\begin{array}{c}7.6 \\
(62)(56)\end{array}$ & $\begin{array}{l}11.4 \\
(44)(38)\end{array}$ \\
\hline Sierra Leone & 25.9 & 24.1 & 24.9 & $\begin{array}{l}12.2 \\
(53)(50)\end{array}$ & $\begin{array}{c}17.4 \\
(33)(30)\end{array}$ \\
\hline
\end{tabular}

TABLE 10. Electricity prices (\$cents/kWh) and LCOE (\$cents/kWh) for PV and dieselpowered systems for the 7 countries under study. Values between brackets represent the diesel-powered systems, respectively. 
To a water tank

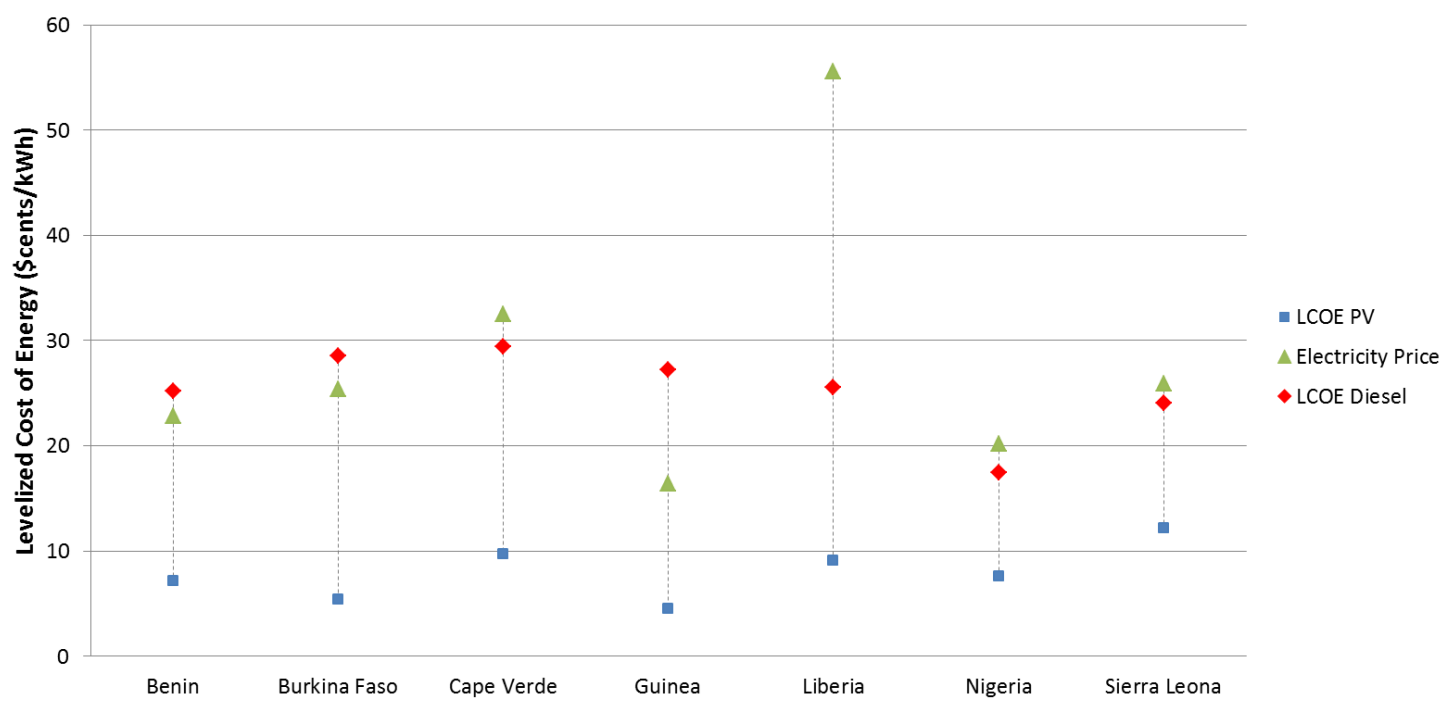

(a)

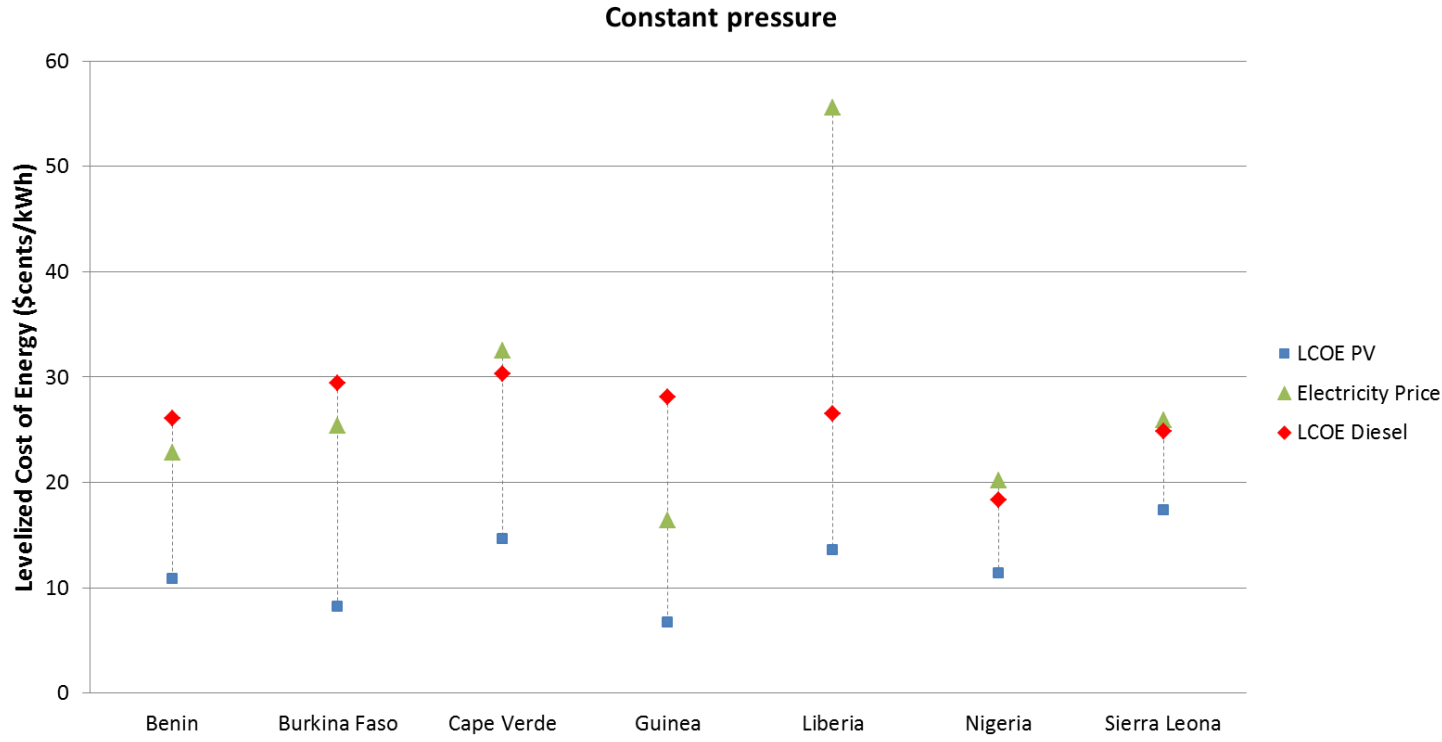

(b)

FIGURE 5. LCOE (\$cents/kWh) for PV-powered and for diesel-powered systems and electricity prices for the 7 countries under study, for systems pumping to a water tank (a) or at constant pressure (b).

3.4 Sensitivity analysis

\subsubsection{Electricity tariffs and diesel prices}

297 A sensitivity analysis has been carried out to consider how the variation in electricity tariffs or 298 diesel prices, which have been historically very unstable in the ECOWAS region (especially the diesel prices), may affect the profitability of the PV irrigation system. Diesel prices have varied by $\pm 25 \%$ of the base case value with an interval step of $5 \%$; electricity tariffs, which are less 
likely to experience significant changes in the near future, have varied by $\pm 10 \%$ of the base case value, with an interval step of $2 \%$.

Figures 6, 7 and 8 detail the variation in NPC, IRR and PBP with DP for systems pumping to a water tank (a) or at constant pressure (b), and their variation with EP for the same two operating modes (c), (d). It can be observed that NPC has a linear correlation with DP and with EP. The slope of the corresponding trend line increases when $i$ decreases (Guinea has the biggest slope and Sierra Leone, the lowest). As well as NPC, IRR presents a linear correlation with DP and $\mathrm{EP}$, although in this case the slope of the corresponding trend line does not depend on $i$, but on both $t$ (higher $t$ means smaller slopes) and DP or EP (higher prices mean bigger slopes). Finally, PBP changes with DP and EP according to a negative exponential trend. The exponent coefficient depends on $t$ (higher income tax rates mean higher coefficients) and on DP or EP (higher prices mean lower coefficients).

In Figure 6(b)-diesel-powered systems pumping at constant pressure-, points with negative NPC values (which imply that the investment of installing a PV irrigation system would not be cost effective) are plotted in bright red. As observed, NPC would be negative in Sierra Leone if DP fell below 5\% of the base case value, in Nigeria if DP fell below $-10 \%$ and in Liberia if DP fell below $-25 \%$. In Figure 7(b), points with IRR values lower than the real discount rate are also plotted in bright red, and they correspond to the same cases that present negative NPC values. For grid-powered systems, NPC is positive and IRR is higher than real discount rates for all the situations considered in this sensitivity analysis. On the other hand, all PBP's obtained are lower by far than the lifetime of the system (25 years), with a maximum value of 14.6 years in the worst case scenario for Nigeria (see Figure 8.b), but with maximum values of 10 years for the rest of the countries.

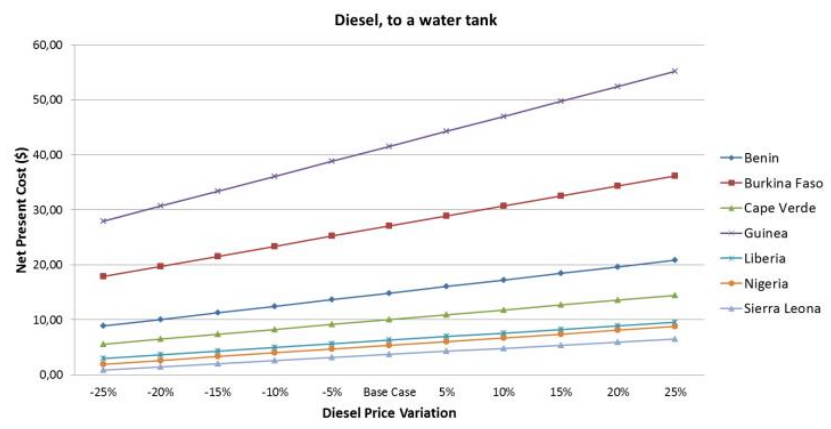

(a)

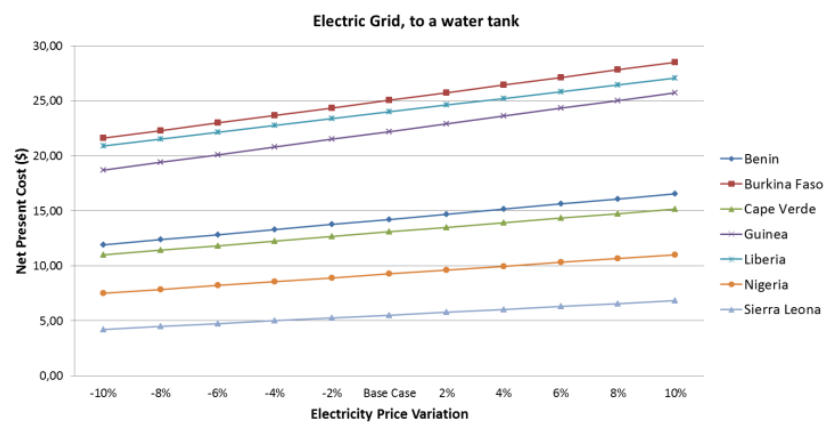

(c)

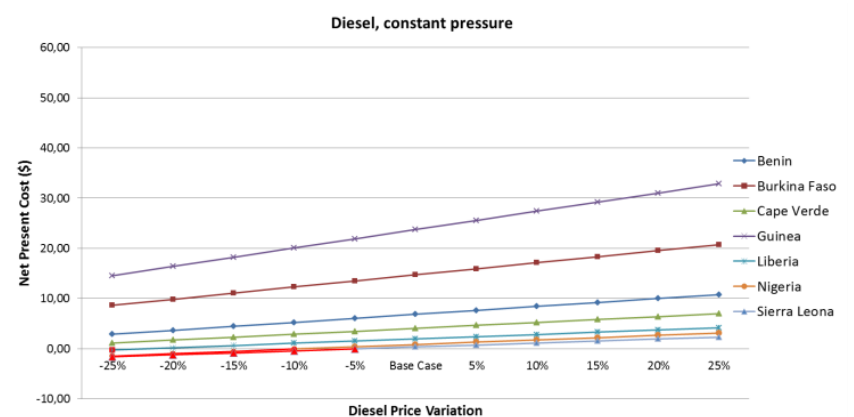

(b)

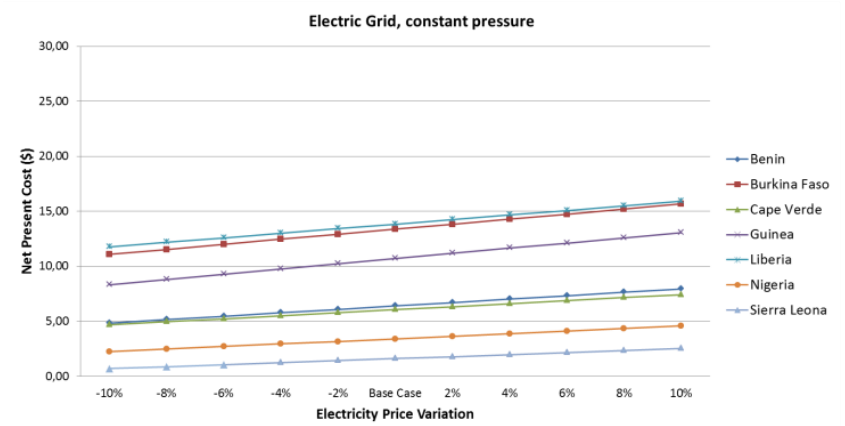

(d) 
FIGURE 6. Variation in NPC (\$) with DP for systems pumping to a water tank (a) or at constant pressure (b) and variation in NPC with EP for the same two operating modes (c), (d). Points plotted in bright red correspond to negative NPC values.

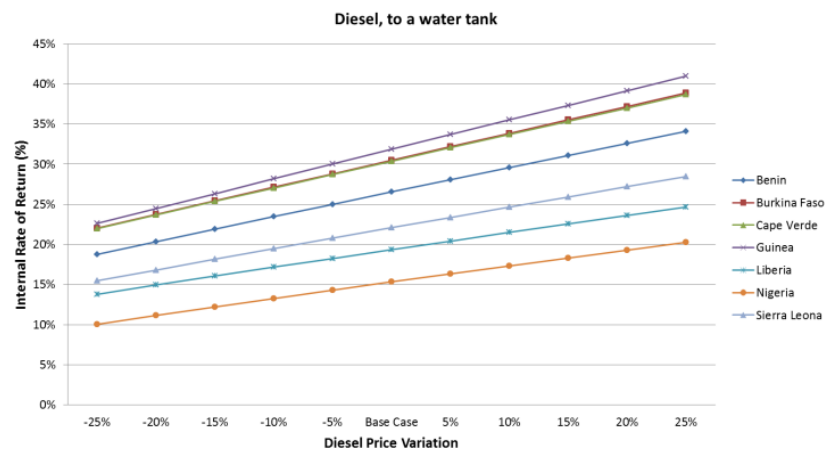

(a)

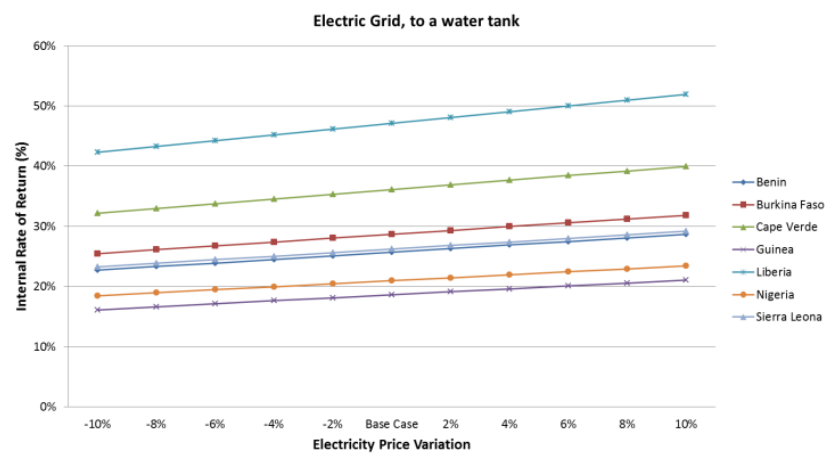

(c)

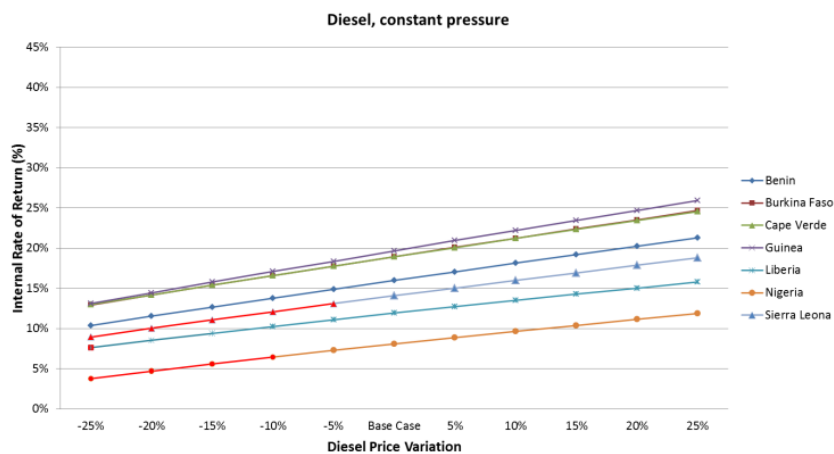

(b)

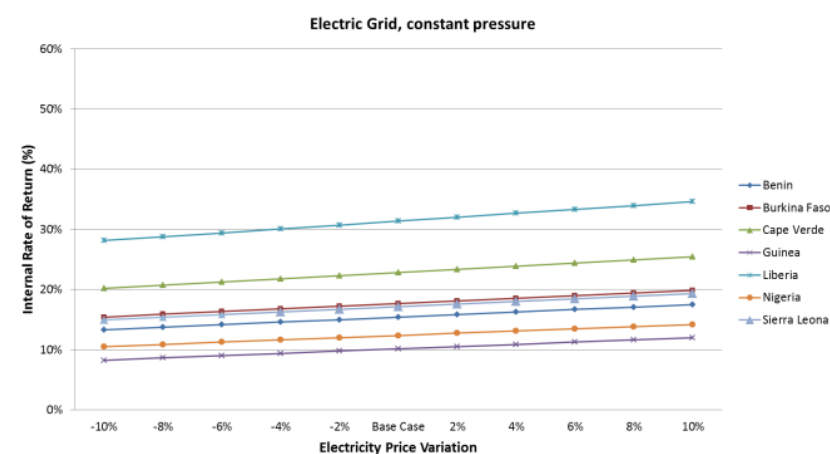

(d)

FIGURE 7. Variation in IRR (\%) with DP for systems pumping to a water tank (a) or at constant pressure (b) and variation in IRR with EP for the same two operating modes (c), (d). Points plotted in bright red correspond to IIR values lower than the local $i$.

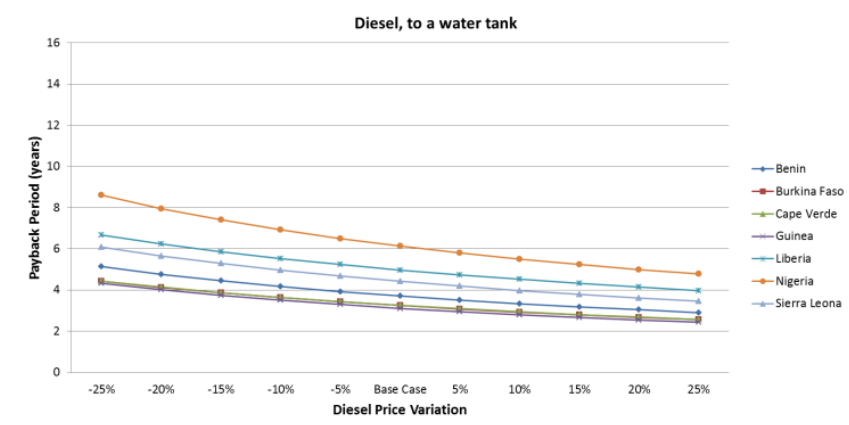

(a)

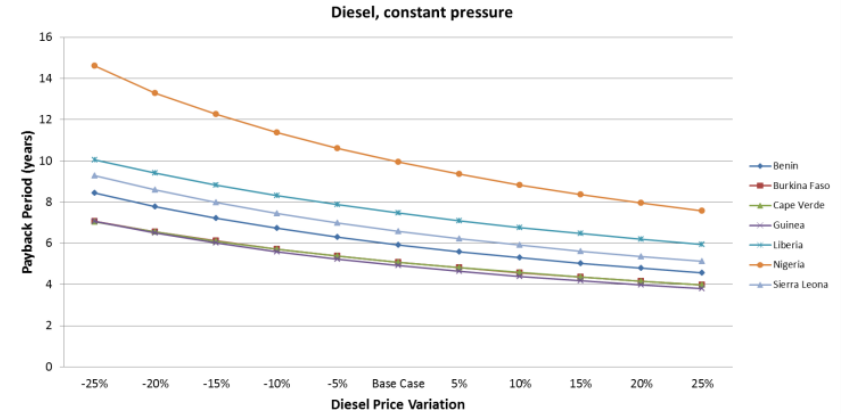

(b) 


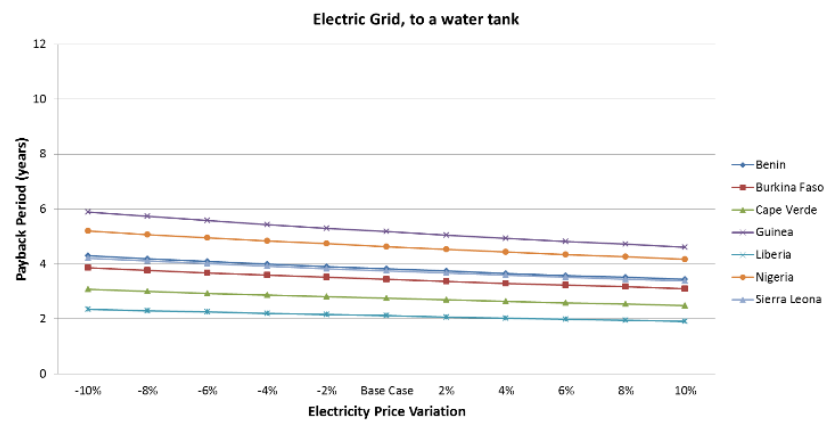

(c)

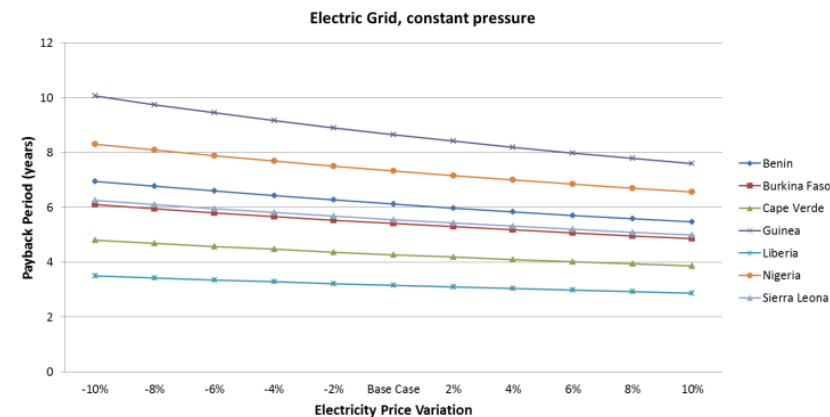

(d)
337

338

339

340

341

342

343

344

345

346

347

348

349

350

351

352

353

354

355

356

357

358
FIGURE 8. Variation in PBP (years) with DP for systems pumping to a water tank (a) or at constant pressure (b) and variation in PBP with EP for the same two operating modes (c), (d).

\subsubsection{System size}

An additional sensitivity analysis has been carried out to consider how the profitability of the system might change with the system size, which mainly affects its pumping efficiency (the larger the PV generator, the higher the pumping efficiency) and its unit costs (the larger the system, the smaller unit costs). Two additional PV irrigation systems have been considered (150 and $45 \mathrm{kWp}$ ), both in the range of what we are here calling "large power". Unit costs of 1.84 and 2.05 \$/Wp have been considered, based on the MASLOWATEN experience with two demonstrators equivalent in size terms [4]. As well as for the base case, a $20 \%$ cost overrun has been assumed in the ECOWAS region compared to the South of Europe.

Tables 11, 12 and 13 show NPC, IRR and PBP values obtained for the $380 \mathrm{KWp}$ system (columns shadowed in grey) and for the two smaller systems considered in this sensitivity analysis. In general terms, smaller systems are less profitable than larger ones, but not significantly. Highlighted values in Tables 11 and 12 correspond to those cases where PV irrigation systems would not be profitable (negative NPC or IRR smaller than the local real discount rate), all of them corresponding to systems pumping at constant pressure. However, it should be noted that such cases are not cost-efficient by a very small margin, so this could be easily improved with slight design modifications to reduce the investment cost.

\begin{tabular}{|c|c|c|c|c|c|c|c|c|c|c|c|c|}
\hline \multirow[b]{2}{*}{ PV Power (kWp) } & \multicolumn{3}{|c|}{ Diesel, to water tank } & \multicolumn{3}{|c|}{ Diesel, constant pressure } & \multicolumn{3}{|c|}{ Grid, to water tank } & \multicolumn{3}{|c|}{ Grid, constant pressure } \\
\hline & 45 & 150 & 380 & 45 & 150 & 380 & 45 & 150 & 380 & 45 & 150 & 380 \\
\hline Benin & 1.5 & 5.6 & 14.9 & 0.7 & 2.6 & 6.8 & 1.4 & 5.3 & 14.2 & 0.6 & 2.4 & 6.4 \\
\hline Burkina Faso & 2.9 & 10.4 & 27.0 & 1.7 & 5.8 & 14.7 & 2.7 & 9.6 & 25.1 & 1.5 & 5.2 & 13.4 \\
\hline Cape Verde & 1.0 & 3.7 & 10.0 & 0.3 & 1.4 & 4.0 & 1.3 & 4.9 & 13.1 & 0.6 & 2.2 & 6.1 \\
\hline Guinea & 4.5 & 16.0 & 41.5 & 2.6 & 9.2 & 23.7 & 2.3 & 8.3 & 22.2 & 1.0 & 4.0 & 10.7 \\
\hline Liberia & 0.6 & 2.3 & 6.3 & 0 & 0.5 & 2.0 & 2.6 & 9.2 & 24 & 1.4 & 5.1 & 13.8 \\
\hline Nigeria & 0.4 & 1.8 & 5.4 & -0.1 & 0.1 & 0.8 & 0.9 & 3.4 & 9.3 & 0.3 & 1.2 & 3.4 \\
\hline Sierra Leone & 0.2 & 1.2 & 3.7 & -0.2 & -0.3 & 0.3 & 0.5 & 1.9 & 5.5 & -0.1 & 0.2 & 1.6 \\
\hline
\end{tabular}
and for the two smaller irrigation systems considered in the sensitivity analysis. 


\begin{tabular}{|c|c|c|c|c|c|c|c|c|c|c|c|c|}
\hline \multirow[b]{2}{*}{ PV Power (kWp) } & \multicolumn{3}{|c|}{ Diesel, to water tank } & \multicolumn{3}{|c|}{ Diesel, constant pressure } & \multicolumn{3}{|c|}{ Grid, to water tank } & \multicolumn{3}{|c|}{ Grid, constant pressure } \\
\hline & 45 & 150 & 380 & 45 & 150 & 380 & 45 & 150 & 380 & 45 & 150 & 380 \\
\hline Benin & 21 & 24 & 27 & 13 & 15 & 16 & 20 & 23 & 26 & 12 & 14 & 15 \\
\hline Burkina Faso & 24 & 28 & 30 & 16 & 18 & 19 & 23 & 26 & 29 & 15 & 17 & 18 \\
\hline Cape Verde & 24 & 28 & 30 & 15 & 18 & 19 & 29 & 33 & 36 & 19 & 21 & 23 \\
\hline Guinea & 25 & 29 & 32 & 16 & 18 & 20 & 14 & 17 & 19 & 7 & 9 & 10 \\
\hline Liberia & 15 & 18 & 19 & 8 & 10 & 12 & 39 & 43 & 47 & 25 & 28 & 31 \\
\hline Nigeria & 12 & 14 & 15 & 6 & 7 & 8 & 16 & 19 & 21 & 10 & 11 & 12 \\
\hline Sierra Leone & 17 & 20 & 22 & 9 & 12 & 14 & 21 & 24 & 26 & 12 & 15 & 17 \\
\hline
\end{tabular}

\section{3}

TABLE 12. IRR values (\%) obtained for the $380 \mathrm{kWp}$ system (columns shadowed in grey) and for the two smaller irrigation systems considered in the sensitivity analysis.

366

\begin{tabular}{l|ccc|ccc|ccc|cc|c|}
\cline { 2 - 13 } & \multicolumn{3}{|c|}{ Diesel, to water tank } & \multicolumn{3}{c|}{ Diesel, constant pressure } & \multicolumn{3}{c|}{ Grid, to water tank } & \multicolumn{2}{c|}{ Grid, constant pressure } \\
\hline PV Power (kWp) & $\mathbf{4 5}$ & $\mathbf{1 5 0}$ & $\mathbf{3 8 0}$ & $\mathbf{4 5}$ & $\mathbf{1 5 0}$ & $\mathbf{3 8 0}$ & $\mathbf{4 5}$ & $\mathbf{1 5 0}$ & $\mathbf{3 8 0}$ & $\mathbf{4 5}$ & $\mathbf{1 5 0}$ & $\mathbf{3 8 0}$ \\
\hline Benin & 4.6 & 4.1 & 3.7 & 7.1 & 6.3 & 5.9 & 4.8 & 4.2 & 3.8 & 7.3 & 6.5 & 6.1 \\
Burkina Faso & 4.0 & 3.5 & 3.2 & 5.9 & 5.4 & 5.1 & 4.3 & 3.8 & 3.4 & 6.3 & 5.7 & 5.4 \\
Cape Verde & 4.0 & 3.6 & 3.3 & 6.1 & 5.5 & 5.1 & 3.4 & 3.0 & 2.8 & 5.1 & 4.6 & 4.3 \\
Guinea & 3.9 & 3.4 & 3.1 & 6.0 & 5.3 & 4.9 & 6.6 & 5.7 & 5.2 & 11.0 & 9.4 & 8.7 \\
Liberia & 6.1 & 5.4 & 5.0 & 9.4 & 8.3 & 7.5 & 2.6 & 2.3 & 2.1 & 4.0 & 3.5 & 3.2 \\
Nigeria & 7.8 & 6.7 & 6.1 & 12.0 & 10.7 & 9.9 & 5.8 & 5.1 & 4.6 & 8.8 & 7.9 & 7.3 \\
Sierra Leone & 5.5 & 4.8 & 4.4 & 9.1 & 7.6 & 6.6 & 4.7 & 4.1 & 3.8 & 7.6 & 6.4 & 5.6 \\
\hline
\end{tabular}

367

368

369

370

371

372

373

374

375

376

377

378

379

380

381

382

383

384

385

386

387
TABLE 13. PBP values (years) obtained for the $380 \mathrm{kWp}$ system (columns shadowed in grey) and for the two smaller irrigation systems considered in the sensitivity analysis.

\section{Discussion}

The first point of discussion on the previous results is that the installation of stand-alone large power PV generators in the ECOWAS region would be very profitable in already existing gridpowered and diesel-powered irrigation systems. The results of this work state that PV irrigation systems are not only advantageous when there is no access to the grid or in regions with unreliable grid service (where diesel generators are used as back-up) as Chandel et al have noted [34]; but also they are actually more cost-effective than the electric grid itself. So, PV irrigation should be implemented even in regions with good grid access.

The second aspect to discuss is the advantages of PV irrigation systems with accumulation in terms of water tanks. Section 3.1. shows that they are more profitable than systems pumping at constant pressure, although this might change if the use of low-pressure sprinklers was considered for the second. Furthermore, pumping to a water tank offers a significant advantage: water can be stored in the tank for its later use when solar radiation it too low, while constantpressure systems need to couple irrigation periods to PV generation (which implies that irrigation is not possible during the night). The use of batteries would be a possible solution for constant-pressure systems, but is has not been considered in this study as they still present some technical and economic challenges, as Campana et al have shown [35]. 
Third, the sensitivity analysis carried out in section 3.4.1 shows that the profitability of large power PV irrigation systems is reasonably independent of possible changes in electricity tariffs or diesel prices. Only diesel-powered systems pumping at constant pressure are likely to become unprofitable in Liberia, Nigeria and Sierra Leone. Nevertheless, diesel prices would need to be reduced by more than $10 \%$, which is not likely to happen in the near future. This means that the investment in PV irrigation systems is protected against these price variations, reducing its risk. As for the sensitivity analysis detailed in section 3.4.2, it can be extracted that the profitability of PV irrigation systems improves for larger systems, and therefore the investment is even more protected against these price changes.

Fourth, it is important to highlight the small PBP values obtained in this work for the four cases under study, which are all lower than half the lifetime of the system. In fact, most cases (except some systems pumping at constant pressure) present PBP values of less than 6 years, which is less than a quarter of the lifetime of the system. These results are aligned with or improve those presented by other authors like Campana et al [20], Chandel et al [34] and Li et al [2]. This implies again a significant reduction in the investment risk associated to the installation of the PV system: the faster the initial investment cost is returned, the less the probability of unforeseen events happening. As for the sensitivity analysis, with the exception of Nigeria with a 25\% reduction in diesel prices for a system pumping at constant pressure, the rest of the countries present a PBP of less than 10 years, which is very competitive and softens the possible risks.

The fifth aspect to discuss is that financing entities have traditionally evaluated the bankability of PV projects by referring to the Performance Ratio (PR) of the system over a whole year of operation. This PR represents the ratio between the PV energy that has actually been generated and the energy that could have ideally been generated for a given yearly irradiation. Results from section 3 have been obtained considering that the PV energy generated is the one resulting from the simulation described in section 2.1, but this generation, and therefore the PR value, is highly affected by factors that do not depend on the PV system quality: seasonal water availability, water usage or the water needs of different crops. This must be taken into account when presenting performance evaluations of this type of system, especially if comparing them to other PV applications. This aspect is very relevant and deserves further research.

Finally, the installation of large power PV irrigation systems demands significant monetary efforts [3], [36], [37], which need to be justified with very detailed business plans based on an economic analysis like the one presented here. Such business plans assume that systems operate both correctly and efficiently during their entire lifetime, and this requires the following [37]: the design of a control logic capable of managing power intermittences due to cloud-passing (that can induce over-voltages in the electric system or water hammers in the hydraulic system, reducing the overall lifetime), the complete integration of the PV system into the preexisting irrigation infrastructure, the use of solar trackers (for matching PV generation and irrigation needs) and the drawing up of technical specifications and quality control procedures to assure the long-term reliability. The future PV irrigation programs should include a comprehensive economic analysis like the one developed in this work and give the greatest importance to these aspects. Solutions to them have been given by the aforementioned initiatives, but they should be adapted to the specific characteristics of each region. 


\section{Conclusions}

433 This paper presents an economic assessment of large power (in the range from tens to hundreds of $\mathrm{kWp}$ ) PV irrigation systems in the ECOWAS region, considering the investment required for their installation. The profitability of this investment was evaluated through three indicators (NPC, IRR and PBP) for 7 different countries and 4 case studies: substitution of diesel generators or the grid with PV irrigation systems, for two operating modes (pumping to a water tank or at constant pressure). Additionally, the LCOE values of a diesel-powered, a gridpowered and a PV irrigation system were estimated for their comparison. Finally, a sensitivity analysis was carried out to evaluate how the three economic indicators can vary with diesel prices (DP), electricity prices (EP) and the size of the system. The following conclusions could be drawn:

In general terms, substituting diesel-powered and grid-powered systems with PV irrigation systems in the region of ECOWAS seems very promising from the economic point of view.

Profitabilities are higher when the irrigation system is pumping to a water tank than at constant working pressure, and they present little sensitiveness to variations in DP or EP and to the size of the system.

In any case, the study here presented is a starting point and is limited to a region and to certain conditions, but it can be extended in the future by means of more detailed considerations:

- Only locations with very high annual irradiances have been considered, but it would be useful to estimate the profitabilities of PV irrigation systems in regions with fewer solar resources available.

- Only PV configurations in stand-alone operation without batteries have been simulated. However, there are many applications where hybrid configurations, whether with the local grid or with other energy sources, are not only possible but also very beneficial (or even the only solution if irrigation during the night is necessary). The analysis of the feasibility of these solutions would be a very interesting future work.

- As mentioned in section 4, the bankability of PV projects is often evaluated through the PR of the system, which in irrigation applications can be affected by external factors. It is recommended that future works include information related to the water availability, water usage and type of crops, in order to perform more accurate and site-specific economic evaluations.

The probable growth in the market of large power PV irrigation systems should be accompanied 
474 schemes. These are the main barriers for the market uptake of these systems once their technical 475 and economic viability have been proven.

\section{Acknowledgements}

478 This work has been partially supported by the African Development Bank through the [ACTC479 WA2] - ECREEE project. It has also been partially supported by MIT Portugal Program on 480 Sustainable Energy Systems and the Portuguese Science and Technology Foundation (FCT), 481 grant PD/BD/105851/2014, and IDL project (UID/GEO/50019/2013) to Rita Hogan Almeida. 482 Finally, this work has been possible thanks to the funding from the European Union's Horizon 4832020 research and innovation program in the project MArket uptake of an innovative irrigation 484 Solution based on LOW WATer-ENergy consumption (MASLOWATEN), under grant 485 agreement $n^{\circ} 640771$. 
487 [1] R. Fu, D. Feldman, R. Margolis, M. Woodhouse, K. Ardani (2017). "U. S. Solar

488 Photovoltaic System Cost Benchmark: Q1 2017.” Oak Ridge (Tennessee), National Renewable

489 Energy Laboratory. Report n: NREL/TP-6A20-68925.

490 [2] G. Li, Y. Jin, M. W. Akram, X. Chen (2017). "Research and current status of the solar 491 photovoltaic water pumping system - A review." Renewable and Sustainable Energy Reviews 492 79: 440-458.

493 [3] S. Mohammed Wazed, B. R. Hughes, D. O'Connor, J. Kaiser Calautit (2018). "A review of 494 sustainable solar irrigation systems for Sub-Saharan Africa." Renewable and Sustainable Energy 495 Reviews 81: 1206-1225.

496 [4] 2015. "Promoting, financing and advising on solar power irrigation systems - Manual and 497 Tools for Development Practitioners". Eschborn (Germany), German International Cooperation 498 Agency (GIZ).

499 [5] 2016. "Solar Powered Irrigation Systems (SPIS) - Technology, Economy, Impacts." 500 Eschborn (Germany), German International Cooperation Agency (GIZ),

501 [6] Project MASLOWATEN. High Power Photovoltaic Irrigation Systems (2017). 502 http://maslowaten.eu/?page id=37\&lang=es

503 [7] ECOWAS Energy Sector Website (2017), http://www.ecowas.int/ecowas-sectors/energy/; 504 [accessed 15 November 2017]

505 [8] K. Auth, E. Musolino (2014). "ECOWAS Renewable Energy and Energy Efficiency Status 506 Report”. Paris (France), ECREEE. Report n: ISBN 978-3-9815934-2-6.

507 [9] D. L. Talavera, G. Nofuentes., J. Aguilera, M. Fuentes (2007). "Tables for the estimation of 508 the internal rate of return of photovoltaic grid-connected systems." Renewable and Sustainable 509 Energy Reviews 11: 447-466.

510 [10] Available at http://sisifo.adminia.es/

511 [11] Available at https://www.homerenergy.com/products/pro/index.html

512 [12] 2017. "Toolbox on Solar Powered Irrigation Systems-Information and Tools for advising 513 on Solar Water Pumping and Irrigation." GIZ Powering Agriculture and FAO. Available at 514 https://energypedia.info/wiki/Toolbox_on_SPIS

515 [13] PVGIS database (2017), http://re.jrc.ec.europa.eu/pvgis; [accessed 20 October 2017]

516 [14] D. G. Erbs, S. A. K., J. A. Duffie (1982). "Estimation of the diffuse radiation fraction for 517 hourly, daily and monthly-average global radiation." Solar Energy 28(4): 293-302.

518 [15] M. Collares-Pereira, A. Rabl. (1979). "The average distribution of solar radiation 519 correlations between diffuse and hemispherical and between daily and hourly insolation values." 520 Solar Energy 22(2): 155-164. 
521 [16] R. Perez, R. Seals, P. Ineichen, R. Stewart, D. Menicucci (1987). "A new simplified

522 version of the Perez Diffuse Irradiance model for tilted surfaces." Solar Energy 39(3): 221-231.

523 [17] F. Martínez-Moreno, J. Muñoz, E. Lorenzo (2010). "Experimental model to estimate 524 shading losses on PV arrays." Solar Energy Materials and Solar Cells 94(12): 2298-2303.

525 [18] K. Kiefer, D. Dirnberger, B. Müller, W. Heydenreich, A. Kröger-Vodde (2010). ”A

526 degradation analysis of PV power plants." 25th European Photovoltaic Solar Energy

527 Conference and Exhibition. Valencia (Spain).

528 [19] Dhiaa Halboot Muhsen, Abu Bakar Ghazali, Tamer Khatib, Issa Ahmed Abed, Emad M. 529 Natsheh (2016). "Sizing of a standalone photovoltaic water pumping system using a multi530 objective evolutionary algorith." Energy 109: 961-973.

531 [20] P. E. Campana, H. Li, J. Zhang, R. Zhang, J. Liu, J. Yan (2015). "Economic optimization 532 of photovoltaic water pumping systems for irrigation." Energy Conversion and Management 95: $533 \quad 32-41$.

534 [21] Boletín Oficial del Estado (2014), https://www.boe.es/boe/dias/2014/11/28/pdfs/BOE-A535 2014-12328.pdf

536 [22] Miguel Redón Santafé, Juan Bautista Torregosa Soler, Francisco Javier Sánchez Romero, 537 Pablo S. Ferrer Gisbert, José Javier Ferrán Gozálvez, Carlos M. Ferrer Gisbert (2014).

538 "Theoretical and experimental analysis of a floating photovoltaic cover for water irrigation 539 reservoirs." Energy 67: 246-255.

540 [23] H. Rezk, G. M. Dousoky (2016). "Technical and economic analysis of different 541 configurations of stand-alone hybrid renewable power systems - A case study." Renewable and 542 Sustainable Energy Reviews 62: 941-953.

543 [24] K. Y. Lau, C. W. Tan, A. H. M. Yatim (2015). "Photovoltaic systems for Malaysian 544 islands: Effects of interest rates, diesel prices and load sizes." Energy 83: 204-216.

545 [25] Doing Business-Getting electricity (2017), 546 http://www.doingbusiness.org/data/exploretopics/getting-electricity; [accessed 24 October 547 2017]

548 [26] Global Petrol Prices (2017), http://www.globalpetrolprices.com/diesel_prices/; [accessed 54920 October 2017]

550 [27] Doing Business-Paying Taxes (2016), 551 http://www.doingbusiness.org/data/exploretopics/paying-taxes; [accessed 8 November 2017]

552 [28] Data World Bank-Lending interest rate (2016),

553 https://data.worldbank.org/indicator/FR.INR.LEND; [accessed 27 October 2017]

554 [29] Data World Bank-Annual GDP deflator annual (2016),

555 https://data.worldbank.org/indicator/NY.GDP.DEFL.KD.ZG; [accessed 27 October 2017]

556 [30] Akarin Intaniwet, Nattaporn Chaiyat (2017). "Levelized electricity costing per carbon

557 dioxide intensity of an organic Rankine cycle by using a water hyacinth-municipal solid waste 558 fuel." Energy 139: 76-88. 
559 [31] Ana Pueyo, Simon Bawakyillenuo, Helen Osiolo (2016). "Costs and Returns of Renewable 560 Energy in Sub-Saharan Africa: a Comparison of Kenya and Ghana." Brighton (UK), Institute of 561 Development Studies. Evidence Report $\mathrm{n}^{\circ} 190$.

562 [32] Cristian Breyer, Alexander Gerlach, Daniel Schäfer, Jürgen Schmid (2010). "Fuel-Parity: 563 new very large and sustainable market segments for PV systems." IEEE Energy Conference.

564 Manama/Bahrain.

565 [33] I. Odeh, Y. G. Yohanis, B. Norton (2006). "Economic viability of photovoltaic irrigation 566 systems." Solar Energy 80: 850-860.

567 [34] S. S. Chandel, M. Nagaraju Naik, Rahul Chandel (2015). "Review of solar photovoltaic 568 water pumping system technology for irrigation and community drinking water supplies."

569 Renewable and Sustainable Energy Reviews 49:1084-99.

570 [35] Pietro Elia Campana, Hailong Li, Jinyue Yan (2015). "Techno-economic feasibility of the 571 irrigation system for the grassland and farmland conservation in China: Photovoltaic vs. wind 572 power water pumping." Energy Conversion and Management 103: 311-320.

573 [36] P. Pavelic, K. G. Villholth, Y. Shu, L-M Rebelo, V. Smakhtin (2013). "Smallholder 574 groundwater irrigation in Sub-Saharan Africa: country-level estimates of development 575 potential." Water International 38:392-407.

576 [37] D. H. Muhsen, T. Khatib, F. Nagi (2017). "A review of photovoltaic water pumping system 577 designing methods, control strategies and field performance.” Renewable and Sustainable 578 Energy Reviews 68:70-86. 